\title{
COMPLEX TREATMENT OF AMYOTROPHIC LATERAL SCLEROSIS PATIENT
}

\author{
Joanna Białkowska ${ }^{1,2}$, Dorota Mroczkowska ${ }^{2}$, Margaret E. Huflejt ${ }^{3}$, Joanna Wojtkiewicz ${ }^{2}$, \\ Tomasz Siwek ${ }^{2,4}$, Monika Barczewska ${ }^{2,4}$ and Wojciech Maksymowicz ${ }^{2,4}$ \\ ${ }^{1}$ Department of Public Health, Faculty of Health Sciences, Collegium Medicum, \\ University of Warmia and Mazury, Olsztyn, Poland; \\ ${ }^{2}$ Clinical University Hospital, Olsztyn, Poland; \\ ${ }^{3}$ Department of Pathophysiology, School of Medicine, Collegium Medicum, \\ University of Warmia and Mazury, Olsztyn, Poland; \\ ${ }^{4}$ Department of Neurology and Neurosurgery, School of Medicine, Collegium Medicum, \\ University of Warmia and Mazury, Olsztyn, Poland
}

\begin{abstract}
SUMMARY - Amyotrophic lateral sclerosis is a progressive and fatal degenerative neuromuscular disease with few if any treatment options and physical rehabilitation addressing specific deficits is the most frequent form of therapy. Patients also suffer from depression and increased anxiety. Our purpose was to assess the neurorehabilitation effectiveness in a patient with amyotrophic lateral sclerosis who underwent stem cell transplantation but refused physiotherapy due to depression. Disease progression was followed using the revised Amyotrophic Lateral Sclerosis Functional Rating Scale bimonthly for six months pre- and then post-stem cell transplantation. Psychological traits were assessed using six standardized tests. Quantitative electroencephalogram diagnostics was performed before the first and after the last neurofeedback session, and sessions were conducted on a 3-times-a-week basis. The physiotherapy protocol included proprioceptive neuromuscular facilitation, electrical modalities unit applied to the lumbar spine area, and breathing, relaxation and walking exercises, among others. Increased motivation and marked decrease in the pain level was associated with the patient's willingness to complete physiotherapy, which resulted in improvements in most neuromuscular deficits and in increased respiratory capacity. During the 12 post-rehabilitation months, progression of the disease decelerated, and a positive behavioral change was noted. The study suggested that neurofeedback could be used as a neurorehabilitation component of the personalized complex rehabilitation protocol in patients with amyotrophic lateral sclerosis.
\end{abstract}

Key words: Biofeedback, psychology; Amyotrophic lateral sclerosis; Depression; Quality of life

\section{Introduction}

Amyotrophic lateral sclerosis (ALS) is a degenerative neuromuscular disorder characterized by progressive loss of both upper motor neurons in the primary motor cortex and lower motor neurons in the brain-

Correspondence to: Dorota Mroczkowska, Clinical University Hospital, al. Warszawska 30, 10-082 Olsztyn, Poland

E-mail: dor.mroczkowska@wp.pl

Received December 7, 2017, accepted March 6, 2018 stem and spinal cord. Initial symptoms of ALS include muscle atrophy and weakness, often followed by spreading paralysis of the voluntary muscles, and eventually the respiratory muscles ${ }^{1}$. The disease is typically fatal within 2-5 years of symptom onset, whereas about $10 \%$ of patients may survive for more than a decade ${ }^{2,3}$. There are currently few if any treatment options, early detection or prevention methods are not yet available, and rehabilitation treatments addressing specific needs and deficits are the most frequent form of therapy 

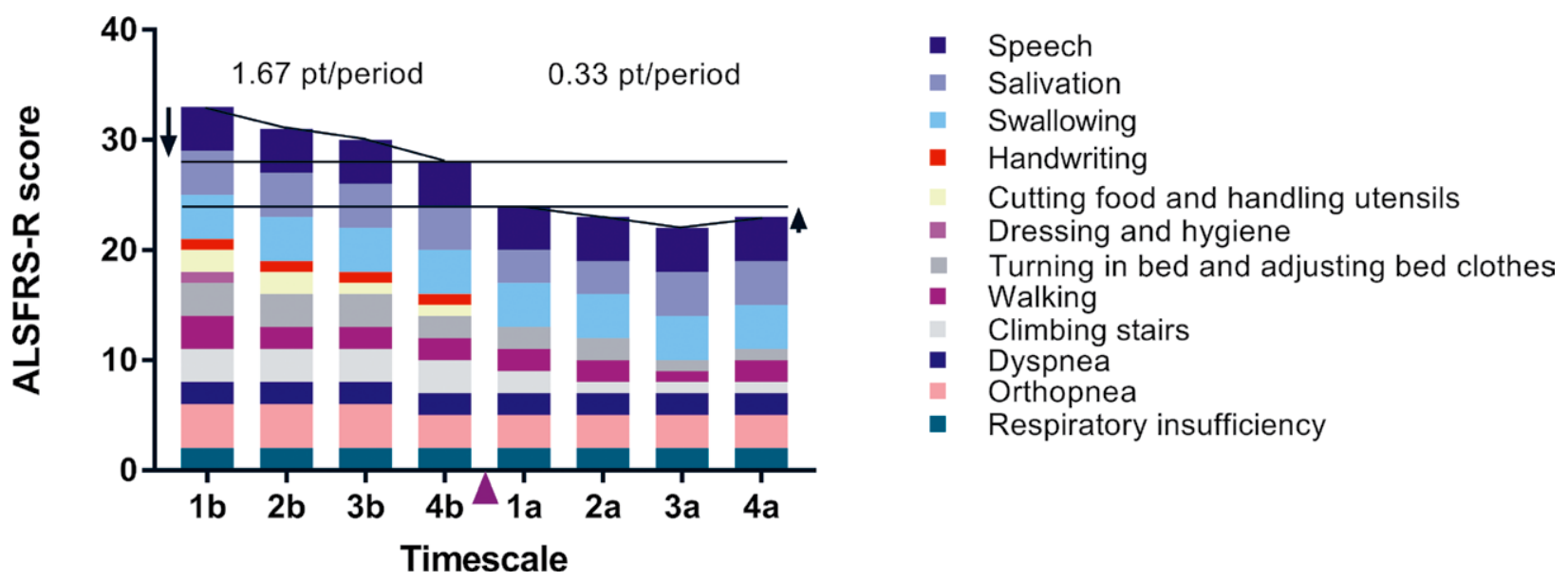

Fig. 1. ALSFRS-R scores reported bimonthly for patient during pre- [1b-4b] and post- [1a-4a] stem cell transplantation period. Arrow indicates the stem cell transplantation time point. The 12 ALSFRS-R scored tasks are listed in the inset, with color shades grouped according to the activity types. The [pt/period] indices represent total bimonthly ALSFRS-R changes in the pre- [1b-4b] and post- [1a-4a] stem cell transplantation period.

ALSFRS-R = Amyotrophic Lateral Sclerosis Functional Rating Scale-Revised

available to most of ALS patients. However, rehabilitation results vary due to the complexity of ALS, broad spectrum of presentation and disease progression rate, and development of individualized, complex rehabilitation protocols is recommended ${ }^{5-9}$.

Patients with ALS also suffer from an additional burden of heavy neuropsychological deficits and imbalances, most prominently of depression and elevated anxiety ${ }^{10,11}$, and have impaired executive functions and social cognition skill tasks ${ }^{12}$. Therefore, there is an urgent need for investigation of methods supplementing individual treatments and rehabilitation protocols that would modify psychological factors to improve the quality of life $\mathrm{e}^{11}$.

One of the potential companion therapies could be electroencephalogram neurofeedback (EEG NFB), neurophysiotherapy and rehabilitation method which employs interaction between the patient's mental state and brain activity, allowing patients to be actively and consciously involved in controlling their own neurophysiological processes ${ }^{13,14}$. Through the evidencebased practice, NFB is gaining attention as a method which has been successfully applied to a wide spectrum of brain-related disorders ${ }^{15}$, most prominently anxiety ${ }^{16}$, sleep quality and insomnia ${ }^{16}$, reducing postoperative pain ${ }^{18}$, epilepsy ${ }^{19,20}$ and stroke ${ }^{21}$.

In the last several years, a substantial progress has been made in developing methods and protocols em- ploying various stem cell types targeting neurodegenerative disorders for single and multiple stem cell transplantations (SCT), and the long-term effects of SCT are anxiously awaited ${ }^{22-27}$. Taking into account these recent progresses, there is the need to continue designing individual complex rehabilitation strategies and to report successful approaches that may improve both the SCT efficacy and the quality of life in ALS.

This report describes evaluation of the NFB effectiveness in the assessment and therapy of cognitive dysfunction, motivation and mood disorders in a 71-year-old patient presenting with ALS who underwent subdural stem cell implantation, but initially refused individually designed rehabilitation. The potential of the NFB as a companion therapy in rehabilitation of ALS patients is discussed.

\section{Patient and Methods}

The patient was a 71-year-old male who first presented in 2007 with discopathy of the cervical and lower lumbar segments, benign prostatic hyperplasia, and vitamin B12 deficiency, and had been treated with nonsteroidal anti-inflammatory drugs and vitamin B12 supplementation. Continuous assistance of a third person was at some point required, and in 2012 the patient was diagnosed with the flail arm syndrome, a variant of ALS, meeting the El Escorial diagnostic cri- 
teria ${ }^{28}$. Noninvasive ventilation became necessary $(8 \mathrm{~h}$ at night and 1-2 $\mathrm{h}$ during the day). Fasciculations were present at multiple sites including muscles of the upper and lower extremities, and right-side Babinski's sign, dystrophy of the chest musculature and muscular dystrophy of the upper limb girdle were confirmed. The patient also presented elevated blood pressure and ischemic cardiovascular disease, and his respiratory insufficiency was diagnosed as the chronic obstructive pulmonary disease (COPD). Despite supplementation, the patient was continuously showing vitamin B12 deficiency. Brain magnetic resonance imaging (MRI) showed small areas of cortical atrophy, and electromyography indicated distal median nerve injury and injury of the motor neurons of the anterior horns of the spinal cord at the C5/C6, C8-Th1, L2-L4, L5$\mathrm{S} 1$ levels, with the features of right upper limb denervation. During his 8-day hospitalization, the patient had physiotherapy sessions which he tolerated very well. At the time of discharge, the patient was recommended to the ambulatory care to continue physiotherapy. Noninvasive ventilation was to be adjusted to his needs. Three arms of medications were administered, as follows: (1) Rilutek, and medications to control (2) ischemic cardiovascular disease and high blood pressure, and (3) COPD.

Three years later, the patient was referred to the Neurological Department, University Hospital in O1sztyn, and his disease status was assessed using the revised version of the ALS Functional Rating Scale-Revised (ALSFRS-R). The scale includes 12 questions, where each task is rated on a five-point scale from $0=$ can't do to $4=$ normal ability, and the individual item scores are summed to produce a reported score between $0=$ worst and $48=$ best. The score obtained at the first evaluation was 33, as shown in Figure 1, and after additional examination the patient was considered a candidate for the Wharton's jelly-derived mesenchymal stem cell transplantation ${ }^{24,26}$. To determine individual rate of ALS progression and then the outcome of the SCT followed by complex rehabilitation, the disease status was assessed using ALSFRS-R bimonthly for six months prior to the SCT, and then every two months post-transplantation. After six months, it was determined that the criteria for SCT set in the Protocol $\mathrm{Nr}$ 32/2013 of the Bioethical Committee at the Faculty of Medical Sciences, University of Warmia and Mazury in Olsztyn were fulfilled, the patient provided his writ- ten informed consent, and $1.8 \times 10^{7}$ stem cells were administered into the subdural space. Following a 12-day postoperative period, the patient was admitted to the clinical rehabilitation center for complex physical and neurological rehabilitation.

At the time of admission, physical examination showed tetraparesis with resultant minor distal weakness, more pronounced in the left limbs, extensive muscular dystrophy of the upper limb girdle and dystrophy of limb musculature, limited precision of finger movements, overall lower muscle strength, extensive fasciculations in the upper body, limited mobility of cervical and lumbar spine, grade 1 right side scoliosis of the thoracolumbar spine, lowered respiratory capacity and lower exercise endurance. The patient complained of severe pain in the extensive spinal area and joints (9/10 points on the visual analog scale, VAS). During the six-minute walk test (6MWT), the patient walked 192 meters with the help of a standard walker, and the Balance + Gait score of the Tinetti Gait and Balance Assessment Tool ${ }^{29}$ was 16/28.

Psychological evaluation revealed multiple cognitive deficits and moderate depression. The patient's psychological and personality traits were assessed using a series of standardized tests including Spielberg State-Trait Anxiety Inventory, Eysenck Personality Questionnaire, The Hamilton Rating Scale for Depression, Common Task Test, Addenbrooke's Cognitive Examination - Final Revised Version, and the Raven Matrices Test. The goals of the tests and the results obtained are shown in Table 1. It was determined that the patient suffered from increased anxiety, had a conscious feeling of fear, guilt and stress, and showed increased intensity of neuroticism, extraversion and psychoticism. The patient also demonstrated irritability, low mood and depression, impaired abilities to plan and perform more complex tasks, impaired cognitive and sequential information-processing abilities, and deterioration of attention/orientation, memory, verbal fluency and visuospatial abilities. The interview with his family members using The Informant Questionnaire on Cognitive Decline in the Elderly Questionnaire revealed a decline of memory and executive/decision making functions at an average level as compared to the overall patient's functioning 10 years before.

Following examinations, an individual experimental physiotherapy protocol was developed taking into account specific patient deficits and needs. Types and 
Table 1. Assessment of the patient's psychological and personality traits prior to rehabilitation

\begin{tabular}{|c|c|c|}
\hline Assessment goal & Results & Conclusions \\
\hline \multicolumn{3}{|c|}{ STAI - Spielberger State-Trait Anxiety Inventory } \\
\hline $\begin{array}{l}\text { Measure of trait and } \\
\text { state anxiety }\end{array}$ & $\begin{array}{l}\text { Anxiety as a trait - sten } \\
7 / 10 \\
\text { Anxiety as a state - sten } \\
4 / 10\end{array}$ & $\begin{array}{l}\text { Moderate tendency to perceive minor threatening situations as } \\
\text { serious endangerments and reaction to these with anxiety and } \\
\text { fear, which indicates that this patient did not suffer earlier from } \\
\text { an anxious personality disorder. In the current situation, } \\
\text { however, the patient suffers from elevated anxiety and conscious } \\
\text { feeling of fear and stress, with accompanying activation of the } \\
\text { autonomic nervous system. }\end{array}$ \\
\hline \multicolumn{3}{|c|}{ Eysenck Personality Questionnaire (EPQ) } \\
\hline $\begin{array}{l}\text { Assessment of the } \\
\text { personality traits }\end{array}$ & $\begin{array}{l}\text { Neuroticism 6/10, } \\
\text { Extraversion } 7 / 10, \\
\text { Psychoticism } 4 / 10 \\
\text { Lie 6/10, } \\
\text { Agreeableness } 5 / 10 \\
\end{array}$ & $\begin{array}{l}\text { Moderate increase in intensity of neuroticism, extraversion, } \\
\text { psychoticism, agreeableness, tendency to lie. }\end{array}$ \\
\hline \multicolumn{3}{|c|}{ Hamilton Rating Scale for Depression (HRS) } \\
\hline $\begin{array}{l}\text { Mood and depression } \\
\text { assessment }\end{array}$ & Score: $17 / 58$ & Low mood, moderate depression. \\
\hline \multicolumn{3}{|l|}{ Common Task Test } \\
\hline Executive functions & $\begin{array}{l}\text { CTT1 - ten } 43 / 100 \\
\text { CTT2 - ten } 31 / 100\end{array}$ & $\begin{array}{l}\text { Impaired abilities to plan and perform more complex tasks; lack } \\
\text { of focus on the external stimuli; low resistance to distraction; } \\
\text { impaired attention types: sustained, divided and alternating; } \\
\text { impaired cognitive and sequential information-processing } \\
\text { abilities. }\end{array}$ \\
\hline \multicolumn{3}{|c|}{ ACE-R Addenbrooke's cognitive examination - Final Revised Version } \\
\hline $\begin{array}{l}\text { Assessment of } \\
\text { attention/orientation, } \\
\text { memory, verbal fluency, } \\
\text { visuospatial abilities, } \\
\text { language functioning }\end{array}$ & $\begin{array}{l}\text { Attention/orientation } \\
(15 / 18), \text { memory } \\
(13 / 26), \text { verbal fluency } \\
(10 / 14), \text { visuospatial } \\
(8 / 16) \\
\text { language }(26 / 26)\end{array}$ & $\begin{array}{l}\text { Deterioration of attention/orientation, memory, verbal fluency } \\
\text { and visuospatial abilities; no deficits in language functioning. }\end{array}$ \\
\hline \multicolumn{3}{|l|}{ Raven Matrices Test } \\
\hline $\begin{array}{l}\text { Assessment of } \\
\text { intellectual abilities }\end{array}$ & $\begin{array}{l}\text { sten } 7 / 10 \text { (percentile } \\
77 / 100)\end{array}$ & Above average \\
\hline \multicolumn{3}{|c|}{ IQCODE Questionnaire } \\
\hline $\begin{array}{l}\text { Assessment of patient's } \\
\text { functioning compared } \\
\text { with } 10 \text { years before }\end{array}$ & \multicolumn{2}{|c|}{$\begin{array}{l}\text { Decline of memory and executive/decision making functions at the average level as } \\
\text { compared to the overall patient's functioning } 10 \text { years before was established during the } \\
\text { interview with his family members. }\end{array}$} \\
\hline
\end{tabular}

schedules of exercises are listed in Table 2. Special attention was paid to the exercise sessions including proprioceptive neuromuscular facilitation, passive stretching of shoulder joints, as well as passive and progressive resistive exercises of lower extremities, manual therapy including classic massage techniques to shoulder girdle and upper extremity musculature, electrical modalities including Transcutaneous Electrical Nerve
Stimulation unit applied to the lumbar spine area, breathing and relaxation exercises, vestibular exercises, and walking training using a standard walker. All exercises were to be carried out under supervision of a physician-physiotherapist, who also had daily Monday-Saturday consultations with the patient.

However, the mobility exercises were initially very difficult to carry out due to the patient's low mood and 
Table 2. Experimental physiotherapy protocol developed for rehabilitation following stem cell transplantation

\begin{tabular}{|c|c|}
\hline Type of exercises & Schedule of exercises \\
\hline Proprioceptive Neuromuscular Facilitation (PNF) & 1x daily, $6 \mathrm{x}$ per week, 30 min sessions \\
\hline $\begin{array}{l}\text { Passive stretching exercises of shoulder joints, as well as } \\
\text { passive and progressive resistive exercises of lower extremities }\end{array}$ & 1x daily, $6 \mathrm{x}$ per week, 30 min sessions \\
\hline $\begin{array}{l}\text { Manual therapy including classic massage techniques to } \\
\text { shoulder girdle and upper extremity musculature }\end{array}$ & 1x daily, $6 \mathrm{x}$ per week, 30 min sessions \\
\hline Trigger point therapy & $1 \mathrm{x}$ daily, $3 \mathrm{x}$ per week, 20 min sessions \\
\hline Manipulative techniques & 1x daily, $6 \mathrm{x}$ per week, 30 min sessions \\
\hline $\begin{array}{l}\text { Electrical modalities including TENS unit applied to the } \\
\text { lumbar spine area }\end{array}$ & $1 \mathrm{x}$ daily, $6 \mathrm{x}$ per week, 20 min sessions, 15 days \\
\hline $\begin{array}{l}\text { Laser applied to painful areas, shoulder girdle and lumbar } \\
\text { spine area }\end{array}$ & $1 \mathrm{x}$ daily, duration: 3 min., $6 \mathrm{x}$ per week, 20 days \\
\hline $\begin{array}{l}\text { Warm gel compresses applied to painful areas including } \\
\text { shoulder joints }\end{array}$ & $1 \mathrm{x}$ daily, every day, $2 \times 20 \mathrm{~min}$ \\
\hline Breathing and relaxation exercises & 1x daily, $6 \mathrm{x}$ per week, $1 \mathrm{x} 20 \mathrm{~min}$ \\
\hline Vestibular exercises & $1 \mathrm{x}$ daily, $6 \mathrm{x}$ per week, $1 \mathrm{x} 20 \mathrm{~min}$ \\
\hline Walking training using standard walker & $\begin{array}{l}3 \mathrm{x} \text { daily, training duration depending on patient } \\
\text { condition and willingness, starting with } 5 \mathrm{~min} \text {, } \\
\text { gradually increasing to } 3 \times 20 \text { min daily }\end{array}$ \\
\hline
\end{tabular}

Unless otherwise stated, all types of exercises listed were carried out throughout the 30 -day rehabilitation period

progressing depression, and his refusal to continue the given task. His communication with the rehabilitation facility staff became increasingly more difficult. At this point, a decision was made to implement electroencephalogram neurofeedback (EEG NFB) therapy. The general principles and goals of the NFB training were explained to the patient and he agreed with this approach.

A quantitative electroencephalogram (QEEG) diagnostics performed prior to the EEG NFB therapy assessed the effect of the neurofeedback method on the neurophysiological parameters in the EEG recording of the $\beta, \beta 2$, waves, sensorimotor rhythm (SMR) and $\tau$ waves. The first test demonstrated dominance of the SMR activity $(12-15 \mathrm{~Hz})$ and $\beta$ waves $(15-20 \mathrm{~Hz})$ in the left brain hemisphere ( $\beta$ waves were correct, and SMR was incorrect), which was consistent with emotional imbalance and attention deficits. The $\delta$ waves (1-3 Hz) and $\tau$ waves $(4-8 \mathrm{~Hz})$ in the central region slightly exceeded the norm of 20 and $10 \mu \mathrm{V}$, respectively. Amplitudes of $\alpha$ waves $(9-12 \mathrm{~Hz})$ were considered normal. The $\beta 2$ waves $(20-34 \mathrm{~Hz})$ for the leads in $\mathrm{C} 3$ and $\mathrm{C} 4$ were above normal. Both elevated $\beta 2 \mathrm{am}-$ plitudes were consistent with emotional tension, fear and mood imbalances. Amplitude values observed in the $\mathrm{C}, \mathrm{F}, \mathrm{Fp}, \mathrm{P}$ and $\mathrm{O}$ leads using the QEEG analyses are presented in Figure 2. The NFB sessions were designed to create optimal conditions for the patient's mental functioning, to achieve the state of simultaneous relaxation and alertness intended to improve therapy for memory function, attention and concentration, and to induce motivation to continue physical therapy. The difficulty level of each of the training sessions was set based on the patient's individual ability, and the length of therapy was established taking into account his personal needs. The training was conducted in a cycle of 10 sessions, on a regular 3-times-a week basis. The time designated to one training session was 30 min. The patient underwent classic $\mathrm{C} 3: \mathrm{C} 4$ training $(\beta / \tau: S M R / \tau)$ with classic frequency settings. The feedback sound was set at 150-200 ms. Rewarding the patient with the visual and sound program effects to increase the sensorimotor waves $(13-15 \mathrm{~Hz})$ along the sensorimotor strip was designed to reduce his impulsive behavior and to induce more frequent reflection prior to undertaking an action. According to Ster$\operatorname{man}^{30}$, strengthening the SMR waves increases the body's ability to maintain homeostasis, and activates alertness and relaxation. In the case described here, during the training with the activities in the $12-15 \mathrm{~Hz}$ 
Amplitudes variability - pre treatment

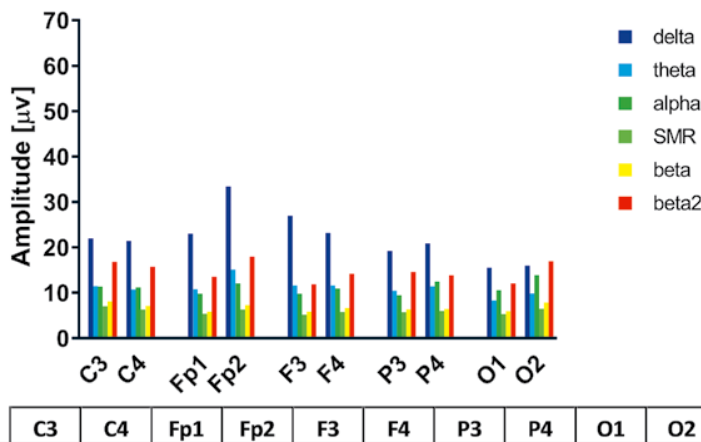

\begin{tabular}{|l|l|l|l|l|l|l|l|l|l|l|l|}
\hline delta & 21.95 & 21.42 & 22.98 & 33.38 & 26.99 & 23.16 & 19.21 & 20.84 & 15.53 & 15.99 \\
\hline
\end{tabular}

\begin{tabular}{|l|l|l|l|l|l|l|l|l|l|l|}
\hline theta & 11.45 & 10.72 & 10.78 & 15.11 & 11.58 & 11.61 & 10.46 & 11.41 & 8.32 & 9.89 \\
\hline
\end{tabular}

\begin{tabular}{|l|l|l|l|l|l|l|l|l|l|l|}
\hline alpha & 11.32 & 11.17 & 9.78 & 12.11 & 9.77 & 10.94 & 9.43 & 12.46 & 10.54 & 13.85 \\
\hline
\end{tabular}

\begin{tabular}{|l|l|l|l|l|l|l|l|l|l|l|}
\hline SMR & 7.03 & 6.33 & 5.36 & 6.29 & 5.16 & 5.76 & 5.7 & 6.01 & 5.29 & 6.44 \\
\hline
\end{tabular}

\begin{tabular}{|l|l|l|l|l|l|l|l|l|l|l|}
\hline beta & 8.13 & 7.1 & 5.84 & 7.3 & 5.84 & 6.67 & 6.37 & 6.43 & 5.97 & 7.89 \\
\hline
\end{tabular}

\begin{tabular}{|l|l|l|l|l|l|l|l|l|l|l|l|}
\hline beta2 & 16.79 & 15.73 & 13.5 & 17.93 & 11.87 & 14.17 & 14.57 & 13.82 & 12.11 & 16.95 \\
\hline
\end{tabular}

Amplitudes variability - post treatment

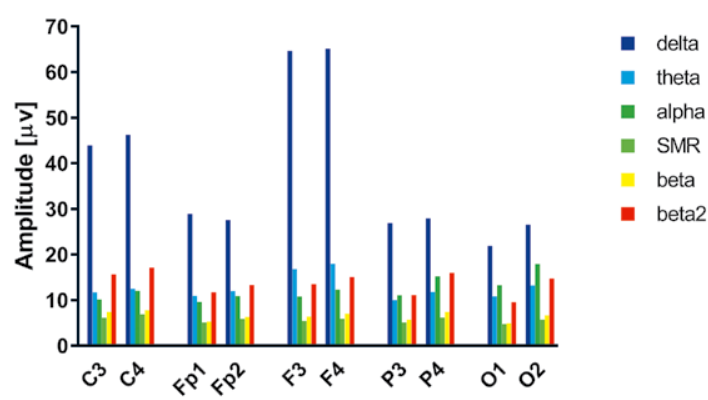

\begin{tabular}{l|l|l|l|l|l|l|l|l|l|} 
C3 & C4 & Fp1 & Fp2 & F3 & F4 & P3 & P4 & 01 & O2 \\
\hline
\end{tabular}

\begin{tabular}{|l|l|l|l|l|l|l|l|l|l|l|}
\hline delta & 43.89 & 46.26 & 28.86 & 27.53 & 64.61 & 65.15 & 26.89 & 27.93 & 21.87 & 26.54 \\
\hline
\end{tabular} \begin{tabular}{|l|l|l|l|l|l|l|l|l|l|l|}
\hline theta & 11.7 & 12.51 & 10.9 & 11.98 & 16.79 & 17.96 & 10 & 11.78 & 10.81 & 13.22 \\
\hline
\end{tabular} \begin{tabular}{|l|l|l|l|l|l|l|l|l|l|l|}
\hline alpha & 10.12 & 12.01 & 9.57 & 10.88 & 10.76 & 12.26 & 11.08 & 15.2 & 13.28 & 17.91 \\
\hline
\end{tabular} \begin{tabular}{|l|l|l|l|l|l|l|l|l|l|l|}
\hline SMR & 6.12 & 6.84 & 5.07 & 5.84 & 5.43 & 5.87 & 5.06 & 6.18 & 4.72 & 5.68 \\
\hline
\end{tabular} \begin{tabular}{|l|l|l|l|l|l|l|l|l|l|l|}
\hline beta & 7.39 & 7.76 & 5.3 & 6.3 & 6.41 & 7.05 & 5.71 & 7.4 & 4.93 & 6.68 \\
\hline
\end{tabular} \begin{tabular}{|l|l|l|l|l|l|l|l|l|l|l|}
\hline beta2 & 15.62 & 17.12 & 11.72 & 13.32 & 13.48 & 15.02 & 11.1 & 15.95 & 9.52 & 14.69 \\
\hline
\end{tabular}

Fig. 2. Pre-vs. post-treatment changes in the amplitudes of the given waves for the respective leads in quantitative EEG analyses.

range, the active electrode was placed in $\mathrm{C} 4$. The goal was to lower the amplitude and percent contribution of the $\tau$ waves ( $4-8 \mathrm{~Hz}$ ) and $\beta 2$ waves (frequency above $18 \mathrm{~Hz}$ ), to reduce the patient's emotional imbalances, elevated anxiety, and akathisia/psychomotor restlessness.

\section{Results}

After the first three NFB sessions, there was clear improvement in the patient's mood and cooperation

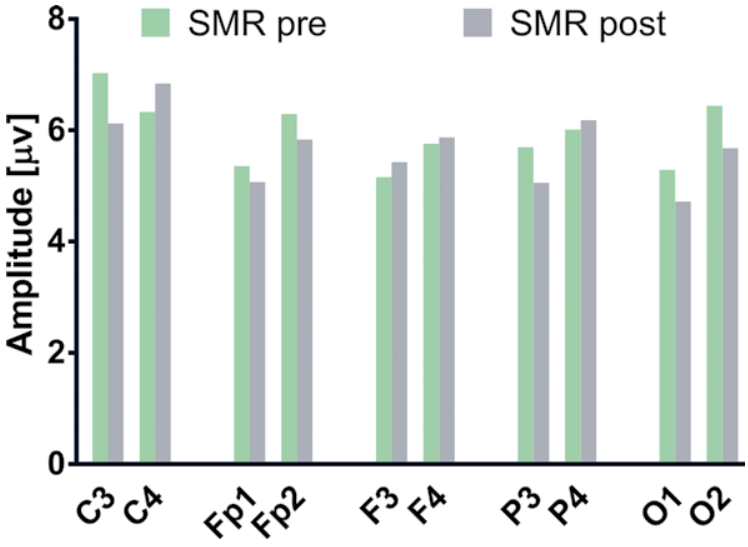

Fig. 3. Pre-vs. post-treatment changes in the amplitudes of $S M R$ waves for the respective leads in quantitative EEG analyses.

SMR = sensorimotor rhythm

with therapists, and his interest in continuing physical therapy exercises at the planned schedule significantly increased. As the result, the entire rehabilitation protocol including NFB sessions was performed as initially designed. After 10 training sessions, an increase in the amplitude of the SMR waves was achieved in the right hemisphere, and the intended reduction of the $\beta$ waves was obtained. The pre- versus post-treatment changes in the amplitudes of the given waves for the respective leads in the QEEG analyses are shown in Figure 2, and the pre- versus post-treatment changes in the amplitudes of SMR waves in Figure 3.

The complex rehabilitation therapy described above resulted in marked improvement of muscle strength in the upper and lower extremities and in the postural muscles. The balance, motion coordination and fine motor skills in lower extremities were improved, and both cardiorespiratory and aerobic endurance increased. The quality and distance of ambulation was also improved. The patient was now able to walk 224 meters with a standard walker during the 6MWT. The pain level decreased by 6 points as per VAS. At discharge from the rehabilitation center, the Balance + Gait score of the Tinetti Gait and Balance Assessment Tool was $21 / 28$. Summary of the major benefits to the patient assessed post 30 -day rehabilitation period is presented in Table 3.

Bimonthly neurological post-rehabilitation evaluations using the ALSFRS-R showed the score drop from 28 to 24, 23 and 22 within the first two, four and 
Table 3. Summary of major benefits for the patient assessed post-30-day rebabilitation period

\begin{tabular}{|c|c|c|}
\hline $\begin{array}{l}\text { Patient evaluation } \\
\text { method }\end{array}$ & $\begin{array}{l}\text { Patient status } \\
\text { / score before } \\
\text { therapy }\end{array}$ & $\begin{array}{l}\text { Patient status } \\
\text { / score following } \\
\text { therapy }\end{array}$ \\
\hline $\begin{array}{l}\text { Visual analog scale } \\
\text { (VAS) }\end{array}$ & $9 / 10$ & $3 / 10$ \\
\hline $\begin{array}{l}\text { Six-minute walk test } \\
(6 \mathrm{MWT})\end{array}$ & 192 meters & 224 meters \\
\hline $\begin{array}{l}\text { Hamilton Rating } \\
\text { Scale for Depression } \\
\text { (HRS) }\end{array}$ & $17 / 58$ & $6 / 58$ \\
\hline $\begin{array}{l}\text { Barthel ADL index } \\
\text { EEG }\end{array}$ & $7 / 20$ & $15 / 20$ \\
\hline $\begin{array}{l}\text { Neurofeedback: } \\
\text { amplitudes of SMR } \\
\text { wave in the C3 point }\end{array}$ & 7.03 & 6.12 \\
\hline $\begin{array}{l}\text { EEG } \\
\text { Neurofeedback: } \\
\text { amplitudes of SMR } \\
\text { wave in the C4 point }\end{array}$ & 6.33 & 6.84 \\
\hline $\begin{array}{l}\text { Measure of state } \\
\text { anxiety }\end{array}$ & sten $4 / 10$ & sten $3 / 10$ \\
\hline Executive functions & $\begin{array}{l}\text { CTT1 - ten } \\
\text { 43/100; } \\
\text { CTT2 - ten } \\
31 / 100\end{array}$ & $\begin{array}{l}\text { CTT1 - ten } \\
46 / 100 ; \\
\text { CTT2 - ten } \\
34 / 100\end{array}$ \\
\hline \multicolumn{3}{|c|}{ Tinetti Gait and Balance Assessment Tool } \\
\hline Gait score & $8 / 12$ & $9 / 12$ \\
\hline Balance score & $8 / 16$ & $12 / 16$ \\
\hline $\begin{array}{l}\text { Total score: balance } \\
+ \text { gait }\end{array}$ & $16 / 28$ & $21 / 28$ \\
\hline
\end{tabular}

six post-transplantation months, respectively, then the score rose slightly to 23 and remained at this level for the next six months, indicating that the disease rate was decelerated, as illustrated in Figure 1. The score drop immediately following SCT could be attributed to the postoperative inflammatory reaction, which had an effect on the patient's daily functioning. The score increase during the post-rehabilitation period resulted mainly from improvement in walking and reduced dyspnea, which allowed the patient to sleep with less pillow support. The patient continued to undergo bimonthly evaluations by the leading neurologist in order to monitor the overall effects of the SCT and complex rehabilitation. Based on the post-hospitalization interviews, it was also noted that the supporting role of the family and social environment could not be underestimated, since it clearly plays an important role in maintaining patient interests in daily life and helps motivate patients to continue the recommended exercises.

\section{Discussion}

To the best of our knowledge, this is the first report of a complex rehabilitation protocol including NFB in the ALS patient having undergone single SCT that resulted in improved ALSFRS-R score, then remaining stable for at least six months. Although in this case most if not all components of the applied therapies contributed to the successful rehabilitation process, it should be stressed that introducing the NFB treatment at the time when the patient started to show signs of a quickly-deepening depression and refused to continue rehabilitation was likely a critical turning point in the post-transplantation period. Relatively quickly achieved alertness and stress reduction resulted in the patient's visibly improved mood, considerably improved communication and cooperation with therapists and increased motivation to continue physical therapy, which certainly made the entire rehabilitation process far more effective.

Depression is a very serious problem in ALS, and antidepressant use is more common in patients with ALS than in controls, especially during the year prior to diagnosis ${ }^{10}$. This most recently reported observation is very significant, since it suggests that certain molecular manifestations of early neuro- and/or neuroimmune degenerative processes may become signals decoded by the brain's deciphering machinery, and then transformed into the conscious perception level as a feeling of depression. Perhaps this new finding will inspire search for these depression-related phenomena as the potential early markers of ALS and maybe of other neurodegenerative disorders.

Since immune dysregulation is one of the major pathophysiology elements underlying $\mathrm{ALS}^{31-35}$, it is tempting to speculate that the neuromodulatory effects of NFB may actually synergize with the immunomodulatory activities of the transplanted stem cells, and thus generated neuroimmune modulation may enhance therapeutic potential of the stem cells alone. So, as the psycho-neuro-immunology is gaining attention as a subject of clinical research ${ }^{36-38}$, NFB may ac- 
tually be a very helpful tool assisting in regulating and organizing this enormously convoluted cross-road. At any rate, studies exploring the potential neuroimmune modulatory effects of NFB in different clinical settings should expand our still very limited understanding of the psycho-neuro-immune connections.

Our patient could be described as a 'responder' to the SCT and to the individually designed complex rehabilitation protocol including NFB sessions. The flail arm syndrome variant of ALS has a slower progression rate and significantly better survival than typical $\mathrm{ALS}^{39}$, and it will be important to determine the effectiveness of NFB as supportive therapy in other ALS phenotypes, and in a larger ALS patient population.

\section{Conclusion}

As the explorations of stem cell types and protocols for single and multiple transplantations continue, parallel efforts aiming at the development of companion complex rehabilitation therapies that would turn therapeutic benefits gained through SCT into the longlasting effects should deliver new ALS treatment options and allow the disease control.

The brain-computer interfaces have already been proven suitable to either expand our understanding of the motoneuron degeneration or showed potential of a positive impact focusing on certain deficits in $\mathrm{ALS}^{40,41}$. Based on our experience reported here, we conclude that NFB can be used as neurorehabilitation therapy supporting individually designed physiotherapy, and may therefore deliver a much sought-after quality of life-improving therapy in the ALS care.

\section{References}

1. Wijesekera LC, Leigh PN. Amyotrophic lateral sclerosis. Orphanet J Rare Dis. 2009;4:3. DOI: 10.1186/1750-1172-4-3

2. del Aguila MA, Longstreth WT Jr, McGuire V, Koepsell TD, van Belle G. Prognosis in amyotrophic lateral sclerosis: a population-based study. Neurology. 2003;60(5):813-9. DOI: 10.1212/01.wnl.0000049472.47709.3b

3. Forsgren L, Almay BG, Holmgren G, Wall S. Epidemiology of motor neuron disease in northern Sweden. Acta Neurol Scand. 1983;68(1):20-9.

4. Orsini M, Lial L, Moreira R, Bastos VH, Pupe C, Bittar C, et al. Rehabilitation in amyotrophic lateral sclerosis: prudence and limit of programs. Int J Phys Med Rehabil. 2015;2(9):1067.
5. Ng L, Khan F. Multidisciplinary rehabilitation in amyotrophic lateral sclerosis. In: Maurer M, editor. Amyotrophic Lateral Sclerosis. 2012; p. 557-78. IntechOpen, DOI: 10.5772/31774. Available from: https://www.intechopen.com/books/amyotrophic-lateral-sclerosis/multidisciplinary-rehabilitation-inamyotrophic-lateral-sclerosis

6. Abresch RT, Han JJ, Carter GT. Rehabilitation management of neuromuscular disease: the role of exercise training.J Clin Neuromuscul Dis. 2009;11:7-21.

7. Ferreira GD, Costa AC, Plentz RD, Coronel CC, Sbruzzi G. Respiratory training improved ventilatory function and respiratory muscle strength in patients with multiple sclerosis and lateral amyotrophic sclerosis: systematic review and meta-analysis. Physiotherapy. 2016;102(3):221-8. DOI: 10.1016/j.physio.2016.01.002

8. Majmudar S, Wu J, Paganoni S. Rehabilitation in amyotrophic lateral sclerosis: why it matters. Muscle Nerve. 2014;50(1): 4-13. DOI: $10.1002 /$ mus. 24202

9. Budinčević $\mathrm{H}$, Budinčević AM, Kos M, Vlašić S, Bartolović J, Benko S, Ostojić V, Butković SS. Multidisciplinary management and neurorehabilitation of patients with amyotrophic lateral sclerosis. Acta Med Croat. 2016;70(2):111-5.

10. Roos E, Mariosa D, Ingre C, Lundholm C, Wirdefeldt K, Roos $\mathrm{PM}$, et al. Depression in amyotrophic lateral sclerosis. Neurology. 2016;86(24):2271-7. DOI: 10.1212/WNL.0000000000 002671

11. van Groenestijn AC, Kruitwagen-van Reenen ET, Visser-Meily JM, van den Berg LH, Schröder CD. Associations between psychological factors and health-related quality of life and global quality of life in patients with ALS: a systematic review. Health Qual Life Outcomes. 2016;14(1):107. DOI: 10.1186/ s12955-016-0507-6

12. Bambini V, Arcara G, Martinelli I, Bernini S, Alvisi E, Moro A, et al. Communication and pragmatic breakdowns in amyotrophic lateral sclerosis patients. Brain Lang. 2016;153-154: 1-12. DOI: $10.1016 /$ j.bandl.2015.12.002

13. Thompson M, Thompson L. The Neurofeedback Book: An Introduction to Basic Concepts in Applied Psychophysiology. Wheat Ridge, CO: Association for Applied Psychophysiology, 2003.

14. Micoulaud-Franchi JA, McGonigal A, Lopez R, Daudet C, Kotwas I, Bartolomei F. Electroencephalographic neurofeedback: level of evidence in mental and brain disorders and suggestions for good clinical practice. Clin Neurophysiol. 2015; 45(6):423-33. DOI: 10.1016/j.neucli.2015.10.077

15. Yucha C, Montgomery D. Evidence-based practice in biofeedback and neurofeedback. Wheat Ridge, CO: Association for Applied Psychophysiology and Biofeedback, 2008. http://digitalscholarship.unlv.edu/nursing_fac_articles/1

16. Cheon EJ, Koo BH, Choi JH. The efficacy of neurofeedback in patients with major depressive disorder: an open labeled prospective study. Appl Psychophysiol Biofeedback. 2016;41(1): 103-10. DOI: 10.1007/s10484-015-9315-8 
17. Schabus M, Heib DP, Lechinger J, Griessenberger H, Klimesch W, Pawlizki A, et al. Enhancing sleep quality and memory in insomnia using instrumental sensorimotor rhythm conditioning. Biol Psychol. 2014;95:126-34. DOI: 10.1016/j.biopsycho.2013.02.020

18. Gorini A, Marzorati C, Casiraghi M, Spaggiari L, Pravettoni G. A neurofeedback-based intervention to reduce post-operative pain in lung cancer patients: study protocol for a randomized controlled trial. JMIR Res Protoc. 2015;4(2):e52. DOI: 10.2196/resprot.4251

19. Sterman MB. Biofeedback in the treatment of epilepsy. Cleve Clin J Med. 2010;77 Suppl 3:S60-7.

20. Daly JJ, Wolpaw JR. Brain-computer interfaces in neurological rehabilitation. Lancet Neurol. 2008;7(11):1032-43. DOI: 10.1016/S1474-4422(08)70223-0

21. Liew SL, Rana M, Cornelsen S, Fortunato de Barros Filho M, Birbaumer N, Sitaram R, et al. Improving motor corticothalamic communication after stroke using real-time fMRI connectivity-based neurofeedback. Neurorehabil Neural Repair. 2016;30(7):671-5. DOI: 10.1177/1545968315619699

22. Karussis D, Karageorgiou C, Vaknin-Dembinsky A, GowdaKurkalli B, Gomori JM, Kassis I, et al. Safety and immunological effects of mesenchymal stem cell transplantation in patients with multiple sclerosis and amyotrophic lateral sclerosis. Arch Neurol. 2010;67(10):1187-94. DOI: 10.1001/archneurol.2010.248

23. Petrou P, GothelfY, Argov Z, Gotkine M, Levy YS, Kassis I, et al. Safety and clinical effects of mesenchymal stem cells secreting neurotrophic factor transplantation in patients with amyotrophic lateral sclerosis: results of phase $1 / 2$ and 2a clinical trials. JAMA Neurol. 2016;73(3):337-44. DOI: 10.1001/jamaneurol.2015.4321

24. Thomsen GM, Gowing G, Svendsen S, Svendsen CN. The past, present and future of stem cell clinical trials for ALS. Exp Neurol. 2014;Pt B:127-37. DOI: 10.1016/j.expneurol. 2014.02.021

25. Frausin S, Viventi S, Verga Falzacappa L, Quattromani MJ, Leanza G, Tommasini A, et al. Wharton's jelly derived mesenchymal stromal cells: biological properties, induction of neuronal phenotype and current applications in neurodegeneration research. Acta Histochem. 2015;117(4-5):329-38. DOI: 10.1016/j.acthis.2015.02.005

26. Alunno A, Montanucci P, Bistoni O, Basta G, Caterbi S, Pescara $\mathrm{T}$, et al. In vitro immunomodulatory effects of microencapsulated umbilical cord Wharton jelly-derived mesenchymal stem cells in primary Sjögren's syndrome. Rheumatology $\left(\mathrm{Ox}^{-}\right.$ ford). 2015;54(1):163-8.

27. Wang Q, Yang Q, Wang Z, Tong H, Ma L, Zhang Y, et al. Comparative analysis of human mesenchymal stem cells from fetal-bone marrow, adipose tissue, and Warton's jelly as sources of cell immunomodulatory therapy. Hum Vaccin Immunother. 2016;12(1):85-96. DOI: 10.1080/21645515.2015.1030549

28. Ludolph A, Drory V, Hardiman O, Nakano I, Ravits J, Robberecht W, et al. Research Group on ALS/MND. A revision of the E1 Escorial criteria - 2015. Amyotroph Lat Scl Fr. 2015; 16(5-6):291-2. DOI: 10.3109/21678421.2015.1049183

29. Tinetti ME, Williams TF, Mayewski R, Fall risk index for elderly patients based on number of chronic disabilities. Am J Med. 1986:80:429-34. DOI: 10.1016/0002-9343(86)90717-5

30. Sterman MB. EEG biofeedback: physiological behavior modification. Neurosci Biobehav Rev. 1981;5(3):405-12.

31. McGrady A, Conran P, Dickey D, Garman D, Farris E, Schumann-Brzezinski C. The effects of biofeedback-assisted relaxation on cell-mediated immunity, cortisol, and white blood cell count in healthy adult subjects. J Behav Med. 1992;15 (4):343-54.

32. Malaspina A, Puentes F, Amor S. Disease origin and progression in amyotrophic lateral sclerosis: an immunology perspective. Int Immunol. 2015;27(3):117-29. DOI: 10.1093/intimm/ dxu099

33. Bahia El Idrissi N, Bosch S, Ramaglia V, Aronica E, Baas F, Troost D. Complement activation at the motor end-plates in amyotrophic lateral sclerosis. J Neuroinflammation. 2016;13 (1):72. DOI: 10.1186/s12974-016-0538-2.

34. Murdock BJ, Bender DE, Kashlan SR, Figueroa-Romero C, Backus C, Callaghan BC, et al. Increased ratio of circulating neutrophils to monocytes in amyotrophic lateral sclerosis. Neurol-Neuroimmunol. 2016;3(4):e242. DOI: 10.1212/NXI.000 0000000000242

35. Czarzasta J, Habich A, Siwek T, Czapliński A, Maksymowicz W, Wojtkiewicz J. Stem cells for ALS: an overview of possible therapeutic approaches. Int J Dev Neurosci. 2017;57:46-55. DOI: 10.1016/j.ijdevneu.2017.01.003

36. Irwin MR. Human psychoneuroimmunology: 20 years of discovery. Brain Behav Immun. 2008;22(2):129-39. DOI: 10.1016/j.bbi.2007.07.013

37. Kemeny ME, Schedlowski M. Understanding the interaction between psychosocial stress and immune-related diseases: a stepwise progression. Brain Behav Immun. 2007;21(8):100918. DOI: $10.1016 /$ j.bbi.2007.07.010

38. Reiche EM, Nunes SO, Morimoto HK. Stress, depression, the immune system, and cancer. Lancet Oncol. 2004;5(10):617-25. DOI: 10.1016/S1470-2045(04)01597-9

39. Wijesekera LC, Mathers S, Talman P, Galtrey C, Parkinson $\mathrm{MH}$, Ganesalingam J, et al. Natural history and clinical features of the flail arm and flail leg ALS variants. Neurology. 2009;72(12):1087-94. DOI: 10.1212/01.wnl.00003450 41.83406.a2

40. Lulé D, Diekmann V, Kassubek J, Kurt A, Birbaumer N, Ludolph AC, et al. Cortical plasticity in amyotrophic lateral sclerosis: motor imagery and function. Neurorehabil Neural Repair. 2007;21(6):518-26.DOI: 10.1177/1545968307300698

41. Marchetti M, Piccione F, Silvoni S, Gamberini L, Priftis K. Covert visuospatial attention orienting in a brain-computer interface for amyotrophic lateral sclerosis patients. Neurorehabil Neural Repair. 2013;27(5):430-8. DOI: 10.1177/154596831 2471903 


\section{Sažetak \\ SLOŽEN PROTOKOL LIJEČENJA BOLESNIKA S AMIOTROFIČNOM LATERALNOM SKLEROZOM}

\section{J. Biatkowska, D. Mroczkowska, M. E. Huflejt, J. Wojtkiewicz, T. Siwek, M. Barczewska i W. Maksymowicz}

Amiotrofična lateralna skleroza je progresivna i smrtonosna degenerativna neuromuskularna bolest za koju postoji malo, ako uopće ijedna mogućnost liječenja pa je najčešći oblik terapije fizikalna rehabilitacija usmjerena na točno određene nedostatke. Ovi bolesnici pate i od depresije te pojačane anksioznosti. Cilj istraživanja bio je procijeniti učinkovitost neurorehabilitacije u bolesnika s amiotrofičnom lateralnom sklerozom koji je podvrgnut transplantaciji matičnih stanica, ali je zbog depresije odbio fizikalnu terapiju. Progresija bolesti praćena je pomoću revidirane Ljestvice za funkcionalnu ocjenu amiotrofične lateralne skleroze svaka dva mjeseca kroz šest mjeseci prije te nakon transplantacije matičnih stanica. Psihološke značajke procjenjivane su pomoću šest standardiziranih testova. Kvantitativna elektroencefalografska dijagnostika provedena je prije prvog i nakon posljednjeg neurofeedback tretmana, koji su se provodili tri puta na tjedan. Protokol fizikalne terapije obuhvaćao je, među ostalim, proprioceptivnu neuromuskularnu facilitaciju, jedinicu električnih modaliteta primijenjenu u području lumbalne kralježnice te vježbe disanja, opuštanja i hodanja. Pojačana motivacija i znatno sniženje razine boli bili su udruženi s bolesnikovim pristankom na potpunu fizikalnu terapiju, što je rezultiralo poboljšanjem većine neuromuskularnih nedostataka i povećanim dišnim kapacitetom. Tijekom 12 mjeseci nakon rehabilitacije progresija bolesti se usporila i zabilježena je pozitivna promjena ponašanja. Ovo istraživanje je pokazalo da se neurofeedback može primijeniti kao neurorehabilitacijska sastavnica personaliziranog složenog protokola rehabilitacije u bolesnika s amiotrofičnom lateralnom sklerozom.

Ključne riječi: Biološka pouratna sprega, psibologija; Amiotrofična lateralna skleroza; Depresija; Kvaliteta života 